\title{
Transfuguismo político: causal de limitación del derecho a la participación política en República Dominicana*
}

[Artículos]

Jesús E. Caldera Ynfante**

Fecha de recepción: 2 de noviembre de 2020

Fecha de aprobación: 16 de diciembre de 2020

Citar como:

Caldera Ynfante, J. E. (2021). Transfuguismo político: causal de limitación del derecho a la participación política en República Dominicana. Via Inveniendi Et Iudicandi, 16(1). https://doi.org/10.15332/19090528.6482

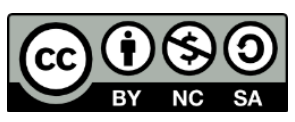

\section{Resumen}

Este artículo analiza el ordenamiento electoral de República Dominicana, en sintonía con una tendencia común del derecho público de Occidente, que tipifica el transfuguismo político-electoral y sanciona la conducta desleal del tránsfuga contra las decisiones o los postulados del

\footnotetext{
* El presente artículo forma parte del proyecto "Fundamentación e implementación de los derechos humanos" del grupo de investigación Persona, Instituciones y Exigencias de Justicia, con Categoría A1 de MinCiencias, vinculado al Centro de Investigaciones Socio Jurídicas de la Universidad Católica de Colombia (CISJUC), de la Universidad Católica de Colombia, del que forma parte el autor.

** Doctor en Derecho por la Universidad Santo Tomás, Colombia. Doctor en Ciencias Jurídicas, Económicas y Sociales por la Universidad de Burgos (España). Profesor de pregrado y posgrados en Derecho Constitucional, Teoría del Estado y de Mecanismos de Protección Internacional de Derechos Humanos en la Universidad Libre, la Universidad Santo Tomás, la Universidad del Sinú y la Universidad La Gran Colombia. Correo electrónico: jecaldera@ucatolica.edu.co, jesuscalderaynfante@gmail.com;

ORCID: https://orcid.org/0000-0002-6776-7308; Scopus ID: 57205325278
} 
partido político, con la limitación de sus derechos políticos pasivos, no pudiendo ser postulado ni ser elegido a cargos de elección popular. El transfuguismo traduce una restricción de tipo legal interno contra todo actor político que traiciona a sus compañeros de partido, a su partido o las decisiones de sus órganos partidarios, pactando con otras fuerzas políticas, basada en normas constitucionales, convencionales y en decisiones de organismos judiciales o instancias internacionales de protección de derechos humanos que, de manera vinculante, por efectos de la cosa interpretada (res interpretata), le confieren legitimidad y validez jurídica a la inhabilitación que se impone al transgresor frente a su conducta de perfidia político-partidista. Esto incluye la restricción del goce de sus derechos políticos pasivos, prohibiéndole ser nominado como candidato a cargos públicos, limitándole el derecho a ser elegido, como consecuencia de prácticas de transfuguismo político-electoral.

Palabras clave: transfuguismo político, partidos políticos, democracia, derechos políticos, elecciones.

\section{Political defection: a cause of limitation of the right to political participation in the Dominican Republic}

\section{Abstract}

This article analyzes the electoral system of the Dominican Republic, in line with a common trend of public law in the West, which typifies political-electoral defection and punishes the disloyal conduct of the defector against the decisions or postulates of the political party, with the limitation of his passive political rights, not being able to be nominated or elected to popularly elected offices. Defection translates into an internal legal restriction against any political actor who betrays his fellow party members, his party or the decisions of party bodies, making agreements with other political forces, based on constitutional and conventional norms and on decisions of judicial bodies or international entities for the protection of human rights which, in a binding manner, 
by effects of the interpreted thing (res interpretata), confer legitimacy and legal validity to the disqualification imposed on the transgressor in view of his conduct of partisanship perfidy. This includes the restriction of the enjoyment of his passive political rights, prohibiting him from being nominated as a candidate for public office, limiting his right to be elected, as a consequence of practices of political-electoral defection.

Keywords: political defection, political parties, democracy, political rights, elections.

\section{Introducción*}

El transfuguismo ${ }^{1}$ político-electoral está regulado en la legislación de República Dominicana para preservar la estabilidad de los partidos políticos, la calidad de la democracia, la lealtad del líder elegido al programa del partido que lo postula y a sus electores, así como la confianza entre los electores de las organizaciones políticas y los candidatos que participan dentro de las elecciones internas partidistas, en los comicios abiertos frente a otros partidos u organizaciones políticas y en las decisiones que los representantes adopten en organismos colegiados como los ayuntamientos (cabildos o concejos) municipales, asambleas legislativas o congresos nacionales, como expresión del parlamento nacional o en elecciones presidenciales. La materialización del transfuguismo supone, en principio, la violación a la normativa legal sobre la materia, que tiene como efecto la imposición de limitaciones regladas sobre los derechos políticos del infractor. Ahora bien, en la praxis política generalizada - a la que no escapa República Dominicana-, la aplicación de las sanciones previstas en las normas electorales frente a los sujetos

\footnotetext{
* Países como México, Colombia, Brasil o España sancionan, con rigor, la deslealtad político-electoral o parlamentaria del transfuguismo.

1 Tránsfuga, aquí empleado como categoría jurídica, sin ánimo peyorativo, entendido como "persona que pasa de una ideología o colectividad a otra", según el Diccionario de la Real Academia de la Lengua Española.
} 
políticos infractores (personas naturales, partidos políticos, directivos partidistas, candidatos) implica que la regulación de los supuestos taxativos del fenómeno del transfuguismo no limita ni impide efectivamente su consumación dado el hecho de la falta de previsión de órganos sancionadores o de ausencia de procedimientos disciplinarios adecuados que conduce a que los entes encargados de su implementación no hacen valer su fuerza imperativa, dejando hacer, dejando pasar, sin reprimenda alguna, actitud que podría configurar una conducta de connivencia frente a las causales de pérfida político-electoral. Como se apreció en las elecciones presidenciales de República Dominicana del 6 de julio de 2020, la cláusula sobre transfuguismo político no fue aplicada conforme la previsión normativa. La Junta Central Electoral y los órganos judiciales (electoral y constitucional) habrían tenido que asumir los costos políticos si hubiesen restringido la participación del candidato cuya voluntad estaría comprendida en el supuesto normativo que configura el transfuguismo - entendido como causal jurídica de limitación del derecho electoral pasivo (derecho a ser elegido) de todo aquel actor políticoelectoral inmerso dentro del tipo del transfuguismo político previsto en el ordenamiento constitucional y electoral dominicano-. Así las cosas, fue notoria la participación electoral del doctor Leonel Fernández ${ }^{2}$ en dichos comicios, dando lugar a la configuración del transfuguismo, como hecho jurídico y político, pues quedó en el tercer puesto de las preferencias de los votantes, luego de la división de su partido, el Partido de la Liberación Dominicana (PLD), y luego pasó a conformar el partido llamado la Fuerza del Pueblo. Independientemente del resultado electoral que haya cosechado, lo diciente es que fue precandidato a la nominación presidencial por el PLD, del que se marcha luego de ser derrotado en la

\footnotetext{
2 Tres veces presidente de República Dominicana y líder por quien profesa el mayor de los respetos y la más sincera consideración el autor de estas líneas.
}

Via Inveniendi Et Iudicandi

e-ISSN: 1909-0528 | DOI: https://doi.org/10.15332/19090528

Vol. 16 N. ${ }^{\circ} 1$ | enero-junio del 2021 
contienda interna, aduciendo fraude electoral en su contra, desacatando el resultado de la voluntad popular del que fue su partido político de siempre, y, por esta razón como candidato presidencial con las banderas de su nuevo partido (Fuerza del Pueblo).

Al margen de la regulación legal electoral, que prohíbe dicha participación, primaron fuertes consideraciones de carácter político para dejarlo concurrir a las elecciones presidenciales, pues su presencia en la carrera presidencial sería un mal menor frente a una eventual inhabilitación político-electoral de su candidatura, que, adoptada en derecho, lo hubiese victimizado o martirizado ante el país y la región pudiendo capitalizar a su favor la eventual la sanción ante el electorado. En este tipo de circunstancias, a la hora de implementar los correctivos previstos en las normas para prevenir todo tipo de deslealtad partidista, se demuestra que no basta su consagración expresa en la regulación legal sino que, para su vigencia y aplicación eficaz, es necesario un férreo compromiso institucional de los órganos sancionadores competentes del Estado, que, ceñidos al debido proceso, deben colocarse por sobre todo tipo de consideraciones extrajurídicas para hacer valer la ley y, con su efectiva aplicación, fortalecer la confianza ciudadana en la democracia y el sistema de partidos políticos como uno de sus pilares esenciales. Las motivaciones políticas, de cálculo partidista, de carácter comunicacional o hasta de naturaleza económica, pesan enormemente en la búsqueda práctica del poder político y, por ende, en la contienda política y electoral, deviniendo en factores reales de poder meta-jurídico que pueden incidir o influir contra la efectividad de las normas legales sancionatorias del transfuguismo político, afectando, a la postre, la credibilidad ciudadana en la legalidad con la que se comportan los actores políticos, la solidez de los partidos políticos y la calidad de la democracia constitucional. 


\section{Marco jurídico nacional que proscribe el transfuguismo electoral como causal de restricción de los derechos políticos del tránsfuga}

Para Caldera Ynfante (2018a; 2019a; 2020b, 2020c) y Caldera Ynfante

et ál. (2018b, 2019b), la democracia es un derecho fundamental destinado

a garantizar el goce efectivo de todos los derechos fundamentales por y

para la persona humana de la comunidad política. La democracia, como

derecho fundamental3, esto es, la democracia integral, está llamada a

realizar el logro del "contenido normativo de la dignidad humana". Vista

desde una perspectiva integral, el derecho fundamental a la democracia

está compuesto por una doble faceta, que contiene el aspecto

procedimental - elecciones y formación del principio de mayorías - y un

aspecto sustancial - disfrute plenamente efectivo de los derechos

fundamentales por todas las personas, sin exclusiones ni

discriminaciones - , cuyo propósito es asegurar la realización del derecho

al proyecto de vida valioso y el derecho a vivir una vida sin temores ni

daños, a favor de cada persona, que además debe satisfacer el derecho de

3 Siguiendo la dogmática de la Corte Constitucional colombiana (Sentencia T-428 de 2012) un derecho fundamental comprende: 1) Su relación funcional para la realización del contenido de la dignidad humana (que comprende, a su vez, vivir en libertad, vivir bien, vivir sin humillaciones); 2) tiene forma de derecho subjetivo (un sujeto beneficiario; un sujeto obligado y un nexo o relación jurídico-constitucional) y 3) existe un consenso de dogmática constitucional, convencional, jurisprudencial o legal que le atribuye tal nivel de relevancia que determina constitucionalmente su aplicación vinculante. La democracia, a su juicio, cumple con tales parámetros de identificación, pudiendo, por tanto, ser calificada con el rango de derecho iusfundamental y que el Estado, sus órganos y agentes están en el deber de promover, asegurar, proteger, garantizar y satisfacer efectivamente a favor de toda persona humana, cuyo cumplimiento puede ser exigido al Estado como sujeto pasivo obligado a su reconocimiento y garantía. La dogmática de los derechos fundamentales se basa en la garantía de la dignidad humana (valor, principio y derecho constitucional per se) y la afirmación del cuidado de la vida humana y la protección de la persona humana en situación de debilidad manifiesta, exclusión, miseria, pobreza o vulnerabilidad, razón de ser de la política, asumida como instrumento para el logro de la felicidad humana, la convivencia armónica, la reducción o superación de la violencia, la seguridad humana, el desarrollo humano integral y, en últimas, de la vida buena de los seres humanos asociados a la comunidad política en libertad, con justicia, seguridad, propiciándoles bienes materiales e inmateriales para vivir una vida decente, una vida con sentido, una vida que valga la pena vivirla.

Via Inveniendi Et Iudicandi

e-ISSN: 1909-0528 | DOI: https://doi.org/10.15332/19090528

Vol. 16 N.o 1 | enero-junio del 2021 
funcionar efectivamente en la sociedad, con oportunidades que le permitan desplegar su capacidades y obtener florecimiento humano mediante la garantía de condiciones materiales e inmateriales que le permitan vivir una vida con sentido de manera decente, donde le poder político, a decir de Caldera Ynfante (2020a), es concebido como una biocracia, en tanto poder dispuesto al cuidado de la vida, la protección de la persona humana y la naturaleza teniendo como paradigma la plena efectividad de todos los derechos humanos de todas las personas. Todo lo anterior, en el marco del Estado democrático constitucional, en el que la realización de la persona humana pasa por la efectiva concreción de los derechos de la persona humana bajo la teoría de la integralidad de los mismos, que los concibe interrelacionados, indivisibles e interdependientes, con lo cual los derechos políticos y, dentro de ellos, el régimen de partidos, forman parte del plexo de los derechos inherentes a la dignidad humana de las personas, siendo que el Estado y las instituciones están llamadas a promover, garantizar, proteger y asegurar su ejercicio y su goce efectivo como elementos medulares del sistema democrático y del ordenamiento constitucional, a decir de Rodríguez (2014). A juicio de Caldera Ynfante (2020a), desde su definición de biocracia, el poder político ha de estar orientado al cuidado de la vida y la protección de la persona humana, en especial, de los más frágiles y vulnerables de la sociedad, a quienes debe permitirse condiciones efectivas para su plena realización humana en tanto gocen efectivamente de sus derechos humanos, todos fundamentales, en aras de la materialización de su proyecto de vida valioso y sin daños, como presupuesto de la felicidad individual -como condición de posibilidad de su contribución voluntaria al bien común- a la que tiene derecho. Esta es la piedra angular del nuevo orden mundial - basado en el artículo 28 de la Declaración Universal de los Derechos Humanos-, para el cual la democracia viene a ser un 
macroderecho o un derecho omnicomprensivo de rango superior que, con su satisfacción, al mismo tiempo realiza y contribuye a la plena y efectiva realización de los demás derechos fundamentales, inherentes a la dignidad de la persona humana, permitiendo que la persona humana alcance su proyecto de vida valioso, que obtenga florecimiento humano, en el marco del Estado democrático constitucional que está vinculado a la categoría de democracia integral.

De otra parte, los derechos políticos y electorales, de origen liberal, no son absolutos. Su esfera de actuación es objeto de límites, por mandato de la ley, para proteger el núcleo esencial de los derechos de las demás personas, el bien común, la seguridad y defensa o la soberanía nacional (Rincón y Peñas, 2015). Incumben al hombre, como persona humana, en lo individual, y como partícipe en la toma de decisiones en la comunidad política, son la base de la democracia y del sistema de partidos para la búsqueda del poder político y el ejercicio de funciones públicas como expresión de la soberanía popular. Piza Escalante (1979, p. 203), expresidente de la Corte Interamericana de Derechos Humanos (Corte IDH), postula que "los derechos de libertad son derechos del hombre 'frente' al Estado y a los demás que, por lo tanto, implican un deber básicamente negativo, de no hacer, y que imponen al Estado abstenerse de violarlos él mismo, proteger al sujeto ante cualquier violación, y a lo sumo, activamente, establecer mecanismos jurídico-formales para su realización”.

Para Hernández (1995, pp. 1041-1042) los derechos políticos son "aquellos que posibilitan la participación de cierto tipo de persona, ciudadanos, en la conformación de la voluntad general del Estado. Son derechos también identificables bajo la denominación de derechos de participación pública o en asuntos públicos". La Comisión Interamericana de Derechos Humanos (CIDH, 2009, Cap. II, Venezuela, párr. 18) indica que los derechos 
políticos son "aquellos que reconocen y protegen el derecho y el deber de todos los ciudadanos de participar en la vida política de su país”. Para la CIDH (2003a, Cap. IV. Cuba, párr. 11) están dotados de dos elementos: el derecho al ejercicio directo del poder y el derecho a elegir a quienes deben ejercerlo. Ello supone una concepción amplia acerca de la democracia representativa que, como tal, descansa en la soberanía del pueblo y en la cual las funciones a través de las cuales se ejerce el poder son desempeñadas por personas escogidas en elecciones libres y auténticas.

Además, indica que "el ejercicio de los derechos políticos es 'inseparable' de los otros derechos humanos fundamentales" (CIHD, 1990a, Cap. I, Haití, párr. 15). A tenor de Dalla Via (2011, pp. 21-22), "no hay derechos políticos sin democracia y no hay democracia sin derechos políticos", incluidos los derechos políticos y electorales, "como un medio para consolidar un régimen de libertad personal y justicia social, en el marco de las instituciones democráticas":

La Corte Interamericana de Derechos Humanos (2010, párr. 172) ha señalado que "la Convención protege los elementos esenciales de la democracia, entre los que se encuentra 'el acceso al poder y su ejercicio con sujeción al Estado de Derecho".

\section{El transfuguismo electoral como causal de restricción de los derechos políticos del tránsfuga en República Dominicana}

Recientemente, el Congreso de la República Dominicana, en ejercicio de su potestad de configuración normativa interna, mediante legislación adoptada siguiendo las pautas constitucionalmente establecidas, tipificó y sancionó la práctica del transfuguismo político-electoral. Consiste en el accionar destinado a traicionar a sus compañeros de partido, a su partido 
o las decisiones de sus órganos partidarios, pactando con otras fuerzas políticas.

Esta normativa establece limitaciones regladas y permitidas a los derechos políticos pasivos (prohibición de ser nominados como candidatos a cargos de elección popular o derecho a ser elegido) 4 a los tránsfugas políticoelectorales, consciente del grave daño que tales conductas desleales y traicioneras entrañan para la confianza pública en la política, la unidad y fortalecimiento de los partidos políticos y para la vitalidad y efectividad del sistema democrático, del que son pilar angular en el Estado constitucional y convencional de derecho que rige dicho país. Para sancionar las prácticas de transfuguismo electoral, el Congreso dominicano aprobó la Ley Orgánica de Régimen Electoral (15 de 2019) y la Ley de Partidos, Agrupaciones y Movimientos Políticos (33 de 2018). A su turno, siguiendo las disposiciones imperativas de la Ley 15 de 2019, la Junta Central Electoral expidió el Reglamento para la Escogencia de Candidatos mediante Convenciones y Encuestas del 7 de mayo de 2019.

La aprobación de esta legislación tiene justificación en el denominado principio del margen de apreciación nacional, concebido como un instrumento argumentativo, una herramienta hermenéutica, surgida en el Sistema Europeo de protección de derechos humanos - extendido al Sistema Interamericano-, que pregona que los Estados, en su quehacer regulatorio interno, cuentan con un ámbito (margen de apreciación nacional) de holgura interpretativa para analizar y dotar de sentido jurídico-legal a las normas convencionales supranacionales, sobre la base del contacto más directo y del conocimiento del entorno social con el que cuentan las autoridades nacionales, especialmente, el Poder Legislativo.

\footnotetext{
${ }^{4}$ Los demás derechos inherentes a la participación política del actor político transgresor, en su faceta activa, no resultan afectados.
}

Via Inveniendi Et Iudicandi

e-ISSN: 1909-0528 | DOI: https://doi.org/10.15332/19090528

Vol. 16 N. ${ }^{\circ} 1$ | enero-junio del 2021 
El Congreso dominicano, haciendo uso del poder regulatorio, también llamado poder de policía, exteriorizado a través de la ley, aprobó la mentada legislación que previene y sanciona el transfuguismo políticoelectoral, fruto de su legitimidad democrática. En esta ley ponderó la razonabilidad y necesidad de limitar, mediante ley orgánica y ley ordinaria, la faceta pasiva del derecho a la participación política (ser nominado como candidato a cargo de elección popular) del tránsfuga, sin menoscabo del contenido esencial de los artículos 25 del Pacto Internacional de Derechos Civiles y Políticos (PIDCP, Organización de las Naciones Unidas, 1976); artículo 8 del Pacto de San José o Convención Americana de Derechos Humanos (CADH, Organización de los Estados Americanos, 1978) y 22 de la Constitución de República Dominicana, toda vez que le está permitido al Congreso dominicano, en ejercicio del aludido poder de policía, regular una situación lesiva a la salud del sistema de partidos y al sistema democrático dominicano.

Dicho poder de policía, en tanto potestad regulatoria, mediante la aprobación de la ley, lo realiza el Congreso, desplegando su libertad de configuración normativa atendiendo los parámetros interpretativos del margen de apreciación nacional frente al derecho convencional citado (PIDCP-CADH), estando habilitado, como se verá más adelante, para limitar la faceta pasiva de los derechos políticos del tránsfuga. Esta actuación busca proteger los bienes jurídicos tutelados que tienen mayor peso constitucional -y que justifican la limitación parcial del derecho del político pasivo del tránsfuga-, como lo son el interés general (sistema democrático constitucional como un todo), el interés colectivo (unidad y fortaleza del partido, movimiento o agrupación política, lealtad para con la comunidad política en general, los electores en particular y para con los compañeros y las banderas de una causa política), que se ven transgredidos cuando el sedicioso partidista o tránsfuga se aparta del 
partido y pacta con otras fuerzas políticas para lesionar los intereses políticos legítimos de sus anteriores compañeros y los de su anterior partido, agrupación o movimiento político.

El Congreso dominicano, en ejercicio de la potestad de configuración normativa, lleva a cabo el poder de policía a partir del conocimiento de la realidad nacional sobre el funcionamiento de los partidos, movimientos y agrupaciones políticas, considerando razonable, necesario y proporcionado proteger el sistema de partidos, como médula del régimen democrático y le confiere rango legal a la perfidia o deslealtad política como causal de restricción de los derechos políticos pasivos del actor responsable de la conducta transgresora merecedora de reproche. De esta forma, los tránsfugas político-electorales deben soportar una restricción parcial del libre ejercicio de sus derechos políticos, mediante la limitación legal de su faceta pasiva, esto es, para ser postulado a cargos de elección popular.

Allí radica, entonces, la factibilidad de que la ley nacional limite el derecho a la participación política pasiva (nominación a cargos de elección popular) del infractor incurso en perfidia político-electoral, ya que la unidad y funcionamiento efectivo de los partidos, movimientos y agrupaciones políticas trasciende lo meramente individual para formar parte de la institucionalidad democrática del país, como expresión del acceso y ejercicio del poder político y del desarrollo de las funciones públicas confiadas por los electores a las organizaciones políticas que llegan a la conducción del Estado dentro de la Constitución, la legalidad especial y la reglamentación regulatoria.

Por ende, la legislación que tipifica, previene y reprende el transfuguismo político-electoral busca que toda persona afiliada a un partido, movimiento o agrupación política ejerza sus derechos a la participación política (activa o pasiva) con lealtad, honradez y transparencia, respetando 
las decisiones de sus órganos internos de decisión y acatando los estatutos de la organización. El que proceda con lealtad y rectitud con lo decidido o reglado por la organización partidista, se hace merecedor de los honores y distinciones de servir a la comunidad y representar al partido de su militancia al acceder popularmente al poder político. Quien obre de modo contrario, incurriendo en prácticas de transfuguismo político-electoral, tendrá que soportar la limitación (restricción parcial) de sus derechos políticos pasivos (para ser nominado como candidato) durante el tiempo y las circunstancias previstas en la ley, debiendo dársele garantías al debido proceso durante la tramitación sancionatoria que pretende reprender la conducta contraventora del sujeto político de que se trate.

\section{La Constitución de la República Dominicana (2015) permite la limitación de los derechos fundamentales solo por ley, respetando su contenido esencial y el principio de razonabilidad}

La Constitución dominicana vigente5, en su artículo 74, sigue la tendencia internacional y se ubica en sintonía con la interpretación más avanzada en materia de derechos fundamentales al considerar que ciertos derechos - entre ellos el de participación política- no son absolutos y pueden ser objeto de limitaciones mediante leyes aprobadas al respecto por el órgano legislativo con sujeción al procedimiento de formación de las leyes.

La Carta Magna dominicana se inscribe en la orientación indicada en la Observación General 25 del Consejo de Derechos Humano de la ONU, acoge el espíritu de sentencias y opiniones consultivas vinculantes de la Corte Interamericana de Derechos Humanos (Corte IDH) y recibe la doctrina de la Comisión Interamericana de Derechos Humanos, puesto que considera permisible, factible y válido que el Estado dominicano,

\footnotetext{
${ }^{5}$ Véase el Título II, Capítulo III: De los principios de aplicación e interpretación de los derechos y garantías fundamentales, artículo $\mathbf{7 4}$ de la norma superior.
}

Via Inveniendi Et Iudicandi

e-ISSN: 1909-0528 | DOI: https://doi.org/10.15332/19090528

Vol. 16 N. ${ }^{\circ} 1$ | enero-junio del 2021 
mediante ley adoptada al respecto, limite o restrinja derechos fundamentales siempre que: 1) la limitación esté contenida en una ley dictada por el Congreso, según sus pautas procedimentales conforme a la Constitución; 2) que se respete su contenido esencial, y que, 3) se ciña al principio de razonabilidad. Así lo señala taxativamente la Constitución dominicana:

Artículo 74. Principios de reglamentación e interpretación. La interpretación y reglamentación de los derechos y garantías fundamentales, reconocidos en la presente Constitución, se rigen por los principios siguientes:

1) No tienen carácter limitativo y, por consiguiente, no excluyen otros derechos y garantías de igual naturaleza;

2) Sólo por ley, en los casos permitidos por esta Constitución, podrá regularse el ejercicio de los derechos y garantías fundamentales, respetando su contenido esencial y el principio de razonabilidad;

3) Los tratados, pactos y convenciones relativos a derechos humanos, suscritos y ratificados por el Estado dominicano, tienen jerarquía constitucional y son de aplicación directa e inmediata por los tribunales y demás órganos del Estado;

4) Los poderes públicos interpretan y aplican las normas relativas a los derechos fundamentales y sus garantías, en el sentido más favorable a la persona titular de los mismos y, en caso de conflicto entre derechos fundamentales, procurarán armonizar los bienes e intereses protegidos por esta Constitución. (C. P., 2015, art. 74, Rep. Dom.)

\section{La Ley Orgánica 15 de 2019 sobre Régimen Electoral previene y sanciona el transfuguismo político}

El Congreso de la República Dominicana, facultado por la Constitución Nacional, tipifica y sanciona el transfuguismo político, limitando 
elementos del derecho a la participación política del tránsfuga, con lo cual restringe válidamente el derecho en referencia consagrado en normas supranacionales del derecho convencional de derechos humanos -que rigen en República Dominicana con eficacia similar a la Constitución Nacional (C. P., 2015, art. 74.3, Rep. Dom.) - como el artículo 25 del PIDCP (ONU, 1976), y el artículo 23 de la CADH (OEA, 1978) y, por consiguiente, restringe, legítimamente, de manera puntual, la faceta pasiva del derecho a la participación política (el derecho a ser elegido, en tanto impide que el tránsfuga sea postulado por partido distinto), contenido del artículo 22 de la Constitución de la República Dominicana6 ${ }^{6}$

La restricción temporal (que no una suspensión) del derecho a la participación política, en su vertiente pasiva, implica una limitación temporal, permisible, factible y plausible según lo pautado en el artículo 74 de la Constitución dominicana vigente, consagrado respetando el denominado orden público internacional y el orden público interamericano, en materia de restricciones permisibles de derechos humanos -basado en normas de ius cogens o de aplicación erga omnesen armonía con la jurisprudencia de la Corte IDH y las decisiones vinculantes del Comité de Derechos Humanos de la ONU, como se verá más adelante.

Para imponer la restricción mediante la Ley 15 de 2019, el Congreso de la República Dominicana estatuyó una restricción o limitación del derecho a la elegibilidad del tránsfuga político, sancionando con la prohibición de ser postulado por partido distinto en el que optó por una nominación electoral

\footnotetext{
6 "Derechos de ciudadanía. Son derechos de ciudadanas y ciudadanos: 1) Elegir y ser elegibles para los cargos que establece la presente Constitución; 2) Decidir sobre los asuntos que se les propongan mediante referendo; 3) Ejercer el derecho de iniciativa popular, legislativa y municipal, en las condiciones fijadas por esta Constitución y las leyes; 4) Formular peticiones a los poderes públicos para solicitar medidas de interés público y obtener respuesta de las autoridades en el término establecido por las leyes que se dicten al respecto; 5) Denunciar las faltas cometidas por los funcionarios públicos en el desempeño de su cargo" (C. P., 2015, art. 22, Rep. Dom.).
}

Via Inveniendi Et Iudicandi

e-ISSN: 1909-0528 | DOI: https://doi.org/10.15332/19090528

Vol. 16 N. ${ }^{\circ} 1$ | enero-junio del 2021 
- así hubiere resultado derrotado-. La restricción, fue adoptada siguiendo los criterios de ponderación, proporcionalidad, razonabilidad, necesidad y utilidad que debe tener rn cuenta el legislador para imponer un límite parcial y transitario sobre un aspecto de los derechos políticos del sujeto transgresor sin afectar sus garantías fundamentales y el núcleo esencial de los demás elementos del derecho a la participación política que el ordenamiento dominicano le reconoce. En esta ley se señala expresamente:

Artículo 2. Definiciones. Para los fines de esta ley y su aplicación, se asumen los siguientes conceptos:

5. Tránsfuga: Se atribuye a aquellos representantes que, traicionando a sus compañeros de partido, o apartándose individualmente o en grupo del criterio fijado por los órganos competentes de las formaciones políticas que los han presentado, o habiendo sido expulsados de estas, pactan con otras fuerzas políticas.

6. Transfuguismo: Especialmente en la vida política, actitud y comportamiento de quien se convierte en tránsfuga.

Artículo 19. Validez de las disposiciones electorales. Las disposiciones de carácter electoral que dicte la Junta Central Electoral, atendiendo a sus facultades reglamentarias, se entenderá que tendrán validez para cada proceso en que sean dictadas las mismas de conformidad con la Constitución y las leyes, las cuales serán conocidas y aprobadas por el Pleno de dicha institución e informadas a los partidos políticos y todos aquellos interesados, por la vía de la notificación correspondiente o la publicación oficial en su página web.

\section{$[\ldots]$}

Via Inveniendi Et Iudicandi

e-ISSN: 1909-0528 | DOI: https://doi.org/10.15332/19090528

Vol. 16 N. ${ }^{\circ} 1$ | enero-junio del 2021 
Artículo 134. Transfuguismo en las candidaturas. Las personas que hayan sido nominadas para ser postuladas por un partido, agrupación, movimiento político o alianza a la cual pertenezca el mismo, a un cargo de elección, no podrán ser postuladas por ningún otro partido, agrupación, movimiento político o alianza, en el mismo proceso electoral.

Artículo 135. Nominación de candidatos. La nominación de los candidatos a cargos electivos que hayan de ser propuestos por un partido político, deberá ser hecha por el voto afirmativo de la mayoría de los concurrentes a las elecciones primarias, convenciones o mecanismos de selección interna, que conforme con sus estatutos convoquen para tales fines las autoridades correspondientes de conformidad con la ley. (Ley 15 de 2019, Rep. Dom.) (énfasis míos)

\section{La Ley 33 de 2018 sobre Partidos, Agrupaciones y Movimientos Políticos previene y sanciona el transfuguismo político}

Además de la anterior argumentación, es pertinente indicar que la restricción igualmente está basada en la Ley 33 de 2018, sobre Partidos Políticos, adoptada por el Congreso de la República Dominicana, siguiendo estándares internacionales, la cual señala:

Artículo 30. Derecho de los miembros. Para garantizar la democracia interna de los partidos, agrupaciones y movimientos políticos quedan establecidos los siguientes derechos a favor de sus miembros: 1) Derecho a la información. Los miembros de un partido, agrupación o movimiento político tienen derecho a acceder a la información sobre el funcionamiento, gestión, planes, tareas, administración de los recursos y actividades que estos desarrollen. Los órganos directivos están en la obligación de rendir informes periódicos a sus integrantes en los plazos establecidos estatutariamente. 
2) Derecho a elección y postulación. Es derecho esencial de los miembros de un partido, movimiento o agrupación política: el elegir y ser elegido para cualquier función de dirigencia o postulación para ocupar un cargo de elección popular, conforme a los requisitos establecidos en la presente ley, sus estatutos, y disposiciones reglamentarias.

\section{$[\ldots]$}

Artículo 49. Requisito para ostentar una precandidatura. Para aspirar y ostentar una precandidatura o candidatura en representación de un partido, agrupación o movimiento político, se requiere:

\section{$[\ldots]$}

4) Que el aspirante a una precandidatura para un determinado evento electoral, en representación de un partido, agrupación o movimiento político no haya participado como candidato por otro partido, agrupación o movimiento político para el mismo evento electoral. (Ley 33 de 2018, Rep. Dom.)

\section{El reglamento para la escogencia de candidatos mediante convenciones y encuestas de $\mathbf{2 0 1 9}$ emitido por la Junta Central Electoral}

A su turno, la Junta Central Electoral, en fecha 7 de mayo de 2019, expidió el Reglamento para la Escogencia de Candidatos Mediante Convenciones y Encuestas, donde, con base en el artículo 19 de la Ley 15 de $2019^{7}$ sobre Régimen Electoral, dejó nítidamente establecida la prohibición del

\footnotetext{
7 Artículo 19. Validez de las disposiciones electorales. Las disposiciones de carácter electoral que dicte la Junta Central Electoral, atendiendo a sus facultades reglamentarias, se entenderá que tendrán validez para cada proceso en que sean dictadas las mismas de conformidad con la Constitución y las leyes, las cuales serán conocidas y aprobadas por el Pleno de dicha institución e informadas a los partidos políticos y todos aquellos interesados, por la vía de la notificación correspondiente o la publicación oficial en su página web" (Ley 15 de 2019, Rep. Dom.).
}

Via Inveniendi Et Iudicandi

e-ISSN: 1909-0528 | DOI: https://doi.org/10.15332/19090528

Vol. 16 N. ${ }^{\circ} 1$ | enero-junio del 2021 
transfuguismo político-electoral y sentó la correcta interpretación y aplicación del artículo 49.4 de la Ley 33 de 2018, ya citada:

Art. 10. Los candidatos que sean postulados en los cargos que han sido reservados para la alta dirección partidaria, deberán cumplir con los requisitos que establecen la Constitución y las leyes en esta materia, excepto aquellos que provienen de otras organizaciones políticas [...] siempre que las mismas no hayan participado en primarias o convenciones de otros partidos, y en las cuales no hubiesen ganado las posiciones a las que fueron propuestos.

\section{Sistema internacional de protección de derechos humanos: limitaciones permitidas sobre los derechos políticos y electorales a tenor de lo indicado por el Comité de Derechos Humanos de la ONU}

Las limitaciones parciales y temporales permitidas sobre el contenido del derecho fundamental a la participación en los asuntos públicos y el derecho de voto, en el orden jurídico interno, están enunciadas, como plausibles y factibles, por ser concordantes con los criterios establecidos en la Observación General No. 25, Comentarios generales adoptados por el Comité de los Derechos Humanos, Artículo 25 sobre "La participación en los asuntos públicos y el derecho de voto", adoptada en el $57^{\circ}$ período de sesiones (U.N. Doc. HRI/GEN/1/Rev.7 at 194, 1996) ${ }^{8}$. Los órganos convencionales universales de protección de los derechos humanos están previstos en los pactos, verbigracia el PIDCP, como instancias para asegurar la efectividad de su cumplimiento aunque en opinión de Cortés (2013, p. 147):

Se está lejos de cumplir de manera satisfactoria, la función de estos mecanismos, no están a la altura de las necesidades, hay mecanismos de

${ }^{8}$ Consultada el 30 de octubre de 2020, visible en:

http://hrlibrary.umn.edu/hrcommittee/Sgencom25.html

Via Inveniendi Et Iudicandi

e-ISSN: 1909-0528 | DOI: https://doi.org/10.15332/19090528

Vol. 16 N.o 1 | enero-junio del 2021 
control no jurisdiccional en Naciones Unidas: comité de derechos humanos, como el procedimiento reglado- contradictorio pero que no acaba en sentencias obligatorias sino en informes y recomendaciones.

\section{Limitaciones permitidas sobre los derechos políticos y electorales a la luz de la observación general 25 del Comité de Derechos Humanos de la ONU-artículo 25 del PIDCP}

Los derechos políticos, contenidos en la III parte del PIDCP (ONU, 1976) están formulados de manera general y sobre ellos se admiten restricciones o limitaciones, mediante la regulación interna de cada Estado parte del pacto, mediante disposiciones expresas de la Ley, aprobada por el órgano con potestad legislativa en lo interno, efectuadas de manera razonable y proporcionada, cuando sea necesario para fines concretos. Uno de ellos, verbigracia, es la prevención y sanción del transfuguismo políticoelectoral. Los artículos 17, 18, 19, 21 y 22 del Pacto expresamente permiten, en mayor o menor medida, alguna suerte de limitación o restricción. De manera particular, el artículo 25 sufre limitaciones o restricciones, mediante leyes particulares, dictadas al afecto, por parte del Estado parte de que se trata a través de la legislación que adopta el Congreso o rama del Poder Legislativo en ejercicio de la potestad-libertad de configuración normativa que detenta, siguiendo los parámetros del margen de apreciación nacional frente al PIDCP y demás normas convencionales universales, continentales o regionales sobre derechos humanos que rigen en el ordenamiento jurídico interno, en virtud del Bloque de Constitucionalidad, luego de aprobados y ratificados conforme al procedimiento indicado en cada Estado, que, a decir de Caldera Ynfante (2012), deviene en herramienta para el examen de constitucionalidas de las leyes, la interpretación constitucional y la garantía y protección efectiva de los derechos fundamentales. 
Si un Estado parte del PIDCP decide aprobar una ley o conjunto de leyes tendientes a limitar o restringir el derecho contenido en el artículo 25 del PIDCP (ONU, 1976), obrando dentro del ámbito competencial permisible o permitido, sin desconocer el contenido esencial del derecho humano fundamental en cita, mi las garantías fundamentales del transgresor, aduciendo el principio de razonabilidad, tal proceder del legislador no equivale a que el Estado parte incurra en una violación, transgresión o desconocimiento de dicho derecho.

La adopción de una limitación o restricción legal del derecho, en el orden interno, permisible para el Estado parte, conlleva una carga de justificación, es decir, se tiene que basar, eso sí, en concretas y determinadas medidas razonables que sustentan la ley que establece la limitación o restricción por parte del Estado sin llegar a anular o vaciar de su contenido esencial, de modo arbitrario, el derecho político determinado puesto en contexto práctico en la vida social y política.

La mentada carga de la justificación - principio de razonabilidad - en los casos específicos sobre derechos humanos concretos, le corresponde inexorablemente al Estado parte, que resultará compelido a evidenciar, de manera suficiente, tanto en el orden interno como en el orden convencional, que la limitación o restricción del derecho del artículo 25 del Pacto obedece a argumentos válidos centrados en razones de legalidad, necesidad, alcance razonable y finalidad legítima. Un actuar discrecional o caprichoso del Estado parte sería una arbitrariedad o un acto abusivo del poder que afecta el contenido del derecho humano fundamental y puede ser examinada por el Comité de Derechos Humanos de la ONU.

La vida, la integridad física y las garantías procesales básicas, como derechos humanos fundamentales, nunca pueden restringirse ni limitarse, al margen de la situación de excepción o la magnitud de la gravedad de las contingencias, coyunturas o circunstancias que viva la comunidad política. 
Está vedado para el Estado Parte suspender su vigencia, impedir su goce efectivo o trabar su disfrute por la persona humana beneficiaria.

No obstante, en el caso del derecho del artículo 25 del PIDCP (ONU, 1976), es plausible y factible la adopción de ciertas limitaciones o restricciones, caso en el cual el derecho el derecho que una persona tiene que sopesarse con el derecho de otras personas, mediante la técnica de la ponderación - teoría del peso específico en caso de conflicto o tensión entre derechos igualmente legítimos - a través de la argumentación jurídica. También es posible que el derecho que una persona tiene sea sopesado con la salvaguarda del bien común, del interés general, de la seguridad y defensa o de la soberanía nacional (ciudadanía) en materia política.

Otra forma de limitar o restringir derechos de las personas, previstos en el PIDCP, es mediante la reserva o declaración oficial que hace el Estado parte al momento de suscribir o adherir, como parte de este, para dejar de aplicar, en jurisdicción de su territorio, una o varias disposiciones de la aludida convención internacional, siguiendo la normativa del derecho internacional, particularmente la contenida en la Convención de Viena sobre el Derecho de los Tratados.

\section{Elementos relevantes de la observación general 25 del Comité de Derechos Humanos de la ONU sobre la adopción de limitaciones o restricciones al derecho humano fundamental a la participación en los asuntos públicos y derecho de voto, artículo 25 del PIDCP}

La Observación General 25, aprobada por el Comité de Derechos Humanos de la ONU en su $1510^{\mathrm{a}}$ sesión ( $57^{\circ}$ período de sesiones) el 12 de julio de 1996 (ONU, 2004, pp. 167 y ss.), forma parte de la doctrina internacional de derechos humanos, la cual rige para el ordenamiento interno de los Estados parte del PIDCP porque: 
1. Es una fuente de derecho directa del derecho internacional de los derechos humanos;

2. Es resultado de una interpretación directa del órgano internacional de protección de derechos humanos convencionalmente establecido en el Pacto;

3. Forma parte del orden público internacional dotado de efectos erga omnes en materia de derechos humanos;

4. El Estado parte (República Dominicana) le atribuye al derecho convencional sobre derechos humanos rango y eficacia constitucional, lo cual comprende y se extiende - por aplicación del Pacto- las decisiones judiciales, las resoluciones en materia de protección del derecho concreto y las interpretaciones -todas vinculantes- del Comité de Derechos Humanos como órgano estatuido para la protección de los derechos fundamentales del PIDCP;

5. El Estado parte no ha formulado reservas sobre la aplicación del artículo 25 del Pacto;

6. El Estado parte reconoce el Bloque de Constitucionalidad o de la aplicación multinivel de normas internas y supranacionales equiparadas al rango de las normas constitucionales para la protección del derecho humano fundamental de que trata el artículo 25 del Pacto.

Indicado lo anterior, cabe resaltar los puntos específicos de la Observación General 25, ya citada, sobre la factibilidad y legitimidad de que el Estado parte adopte limitaciones o restricciones sobre elementos del contenido del artículo 25 del Pacto, teniendo presente cuanto sigue, citado textualmente varios de sus apartes:

\section{$[\ldots]$}

4. Cualesquiera condiciones que se impongan al ejercicio de los derechos amparados por el artículo 25 deberán basarse en criterios 
objetivos y razonables. Por ejemplo, puede ser razonable exigir que, a fin de ser elegido o nombrado para determinados cargos, se tenga más edad que para ejercer el derecho de voto, que deben poder ejercerlo todos los ciudadanos adultos. El ejercicio de estos derechos por los ciudadanos no puede suspenderse ni negarse, salvo por los motivos previstos en la legislación y que sean razonables y objetivos. Por ejemplo, la incapacidad mental verificada puede ser motivo para negar a una persona el derecho a votar o a ocupar un cargo público.

$[\ldots]$

10. El derecho a votar en elecciones y referendos debe estar establecido por la ley y sólo podrá ser objeto de restricciones razonables, como la fijación de un límite mínimo de edad para poder ejercer tal derecho. No es razonable restringir el derecho de voto por motivos de discapacidad física ni imponer requisitos o restricciones relacionados con la capacidad para leer y escribir, el nivel de instrucción o la situación económica. La afiliación a un partido no debe ser condición ni impedimento para votar.

15. La realización efectiva del derecho y la posibilidad de presentarse a cargos electivos garantiza que todas las personas con derecho de voto puedan elegir entre distintos candidatos. Toda restricción del derecho a presentarse a elecciones, como la fijación de una edad mínima, deberá basarse en criterios objetivos y razonables. Las personas que de otro modo reúnan las condiciones exigidas para presentarse a elecciones no deberán ser excluidas mediante la imposición de requisitos irrazonables o de carácter discriminatorio, como el nivel de instrucción, el lugar de residencia o la descendencia, o a causa de su afiliación política. Nadie debe ser objeto de discriminación ni sufrir desventajas de ningún tipo a causa de su candidatura. Los Estados Partes deben indicar y explicar las disposiciones legislativas en virtud de las cuales se puede privar a un grupo o categoría de personas de la posibilidad de desempeñar cargos electivos. 
17. El derecho de las personas a presentarse a elecciones no deberá limitarse de forma excesiva mediante el requisito de que los candidatos sean miembros de partidos o pertenezcan a determinados partidos. Toda exigencia de que los candidatos cuenten con un mínimo de partidarios [para presentar su candidatura] deberá ser razonable y no constituir un obstáculo a esa candidatura. Sin perjuicio de lo dispuesto en el párrafo 1 del artículo 5 del Pacto, las opiniones políticas no deberán usarse como motivo para privar a una persona del derecho a presentarse a elecciones.

\section{$[\ldots]$}

18. En sus informes, los Estados deben describir las disposiciones jurídicas que establecen las condiciones para el ejercicio de cargos públicos electivos, y cualesquiera limitaciones o condiciones aplicables a determinados cargos. También deben describir las condiciones para la designación de los candidatos, por ejemplo, los límites de edad y cualesquiera otras condiciones o restricciones. En los informes, los Estados deben indicar si hay restricciones que impiden que personas que ocupan puestos en la administración pública (inclusive en la policía o las fuerzas armadas) puedan ser elegidas para determinados cargos públicos. Deben describirse los motivos y los procedimientos legales para destituir a personas que ocupan cargos electivos.

\section{$[\ldots]$}

26. El derecho a la libertad de asociación, en particular el derecho a fundar organizaciones y asociaciones interesadas en cuestiones políticas y públicas y a adherirse a ellas es un complemento esencial de los derechos amparados por el artículo 25. Los partidos políticos y sus afiliados desempeñan una función primordial en la dirección de los asuntos públicos y en los procesos electorales. Los Estados deben velar por que, en su organización interna, los partidos políticos respeten las disposiciones aplicables del artículo 25 a fin de que los ciudadanos 
puedan ejercer los derechos que se les garantizan en ese artículo. (ONU, 2014, pp. 168-172) (énfasis mío).

\section{Observación General 31 del Comité de Derechos Humanos de la ONU que permite la adopción de limitaciones o restricciones legales a ciertos derechos del PIDCP}

La Observación General 31 del Comité de Derechos Humanos de la ONU9 impone a los Estados parte el deber de abstenerse de violar los derechos humanos fundamentales reconocidos en el Pacto, indicando que es permisible "cualesquiera restricciones a cualquiera de esos derechos" siempre que el Estado parte demuestre "su necesidad y adoptar únicamente las medidas que resulten proporcionales a la consecución de los legítimos objetivos para lograr una protección constante y eficaz de los derechos del Pacto", sin desconocer su contenido (énfasis mío). Indica la Observación General 31:

6. La obligación jurídica prescrita en el párrafo 1 del artículo 2 es tanto de carácter negativo como positivo. Los Estados partes deben abstenerse de violar los derechos reconocidos por el Pacto y cualesquiera restricciones a cualquiera de esos derechos debe ser permisible de conformidad con las disposiciones pertinentes del Pacto. Cuando se introducen restricciones, los Estados deben demostrar su necesidad y adoptar únicamente las medidas que resulten proporcionales a la consecución de los legítimos objetivos para lograr una protección constante y eficaz de los derechos del Pacto. En ningún caso se deben aplicar las restricciones o invocarse de una manera que menoscabe la esencia de un derecho del Pacto. (ONU, 2004, p. 194)

9 Sobre "la índole de la obligación jurídica general impuesta a los Estados parte en el PIDCP", aprobada el 29 de marzo de 2004. 


\section{Sistema Interamericano de Protección de Derechos Humanos: limitaciones permitidas sobre los derechos politicos y electorales a tenor de la jurisprudencia vinculante, el principio de cosa interpretada y el orden público interamericano}

Las sentencias de la Corte Interamericana de Derechos Humanos (Corte IDH) tienen efectos vinculantes para el Estado parte cuando adquiere el estatus de cosa juzgada formal internacional o cosa juzgada formal interamericana, lo cual conforma un cuerpo dogmático que da contenido al orden público interamericano, el cual se afianza mientras los Estados parte de la Convención Americana de Derechos Humanos (CADH, OEA, 1978), que reconocen la jurisdicción de la Corte IDH, cumplan las sentencias de dicho tribunal internacional y los Estados parte adopten medidas internas y realicen la interpretación y aplicación, en su jurisdicción nacional, de manera tal que cumplan, a su vez, con la obligación estatal ineludible de promover, garantizar, proteger, asegurar y hacer plenamente efectivos los derechos humanos previstos en la $\mathrm{CADH}$, máxime cuando a ello es compelido, de manera vinculante, en la sentencia que decida la responsabilidad internacional del Estado que haya sido proferida en su contra por la Corte IDH. En materia de restricciones sobre derechos políticos, previstos en el artículo 23 de la $\mathrm{CADH}$, tanto la Comisión -en su función de consultiva y de garantía- como la Corte -en su función judicial- han consolidado doctrina y jurisprudencia vinculante al respecto. 


\section{El principio de la cosa interpretada (res interpretata) derivado de la}

cosa juzgada formal de las sentencias de la Corte IDH sobre

restricciones legales a los derechos políticos

Lo anterior significa que, para todos los Estados parte de la CADH ${ }^{10}$ (OEA, 1978), en materia análoga o similar a lo ya fallado en firme, aplica el principio del efecto de cosa interpretada, que dimana de la autoridad interpretativa extensiva de la jurisprudencia de la Corte IDH para casos distintos al sentenciado en el ámbito continental americano de la jurisdicción de los Estados parte de la $\mathrm{CADH}$ que reconocen la potestad judicial del Tribunal Interamericano. Con su interpretación judicial vinculante (cosa interpretada) la Corte IDH refuerza el deber de protección de los Estados parte en materia de respeto y garantía de los derechos humanos, para lo cual resulta imprescindible que el Estado adopte medidas para cumplir con el deber de promover, garantizar, proteger y satisfacer efectivamente los derechos humanos previstos en la $\mathrm{CADH}$, debiendo acometer la adaptación de su normativa interna a los estándares de la misma y la adecuación de la interpretación interna en correspondencia con lo ya fallado por el tribunal interamericano, por parte de jueces y operadores judiciales, ya que la cosa interpretada produce una vinculación jurídica obligatoria y directa para el Estado declarado internacionalmente responsable en materia de derechos humanos, e indirecta para los demás Estados parte de la CADH que reconozcan la competencia judicial de la

10 La CADH, señala lo siguiente: Artículo 23. Derechos Políticos: 1. Todos los ciudadanos deben gozar de los siguientes derechos y oportunidades: a) de participar en la dirección de los asuntos públicos, directamente o por medio de representantes libremente elegidos; b) de votar y ser elegidos en elecciones periódicas auténticas, realizadas por sufragio universal e igual y por voto secreto que garantice la libre expresión de la voluntad de los electores, y c) de tener acceso, en condiciones generales de igualdad, a las funciones públicas de su país. 2. La ley puede reglamentar el ejercicio de los derechos y oportunidades a que se refiere el inciso anterior, exclusivamente por razones de edad, nacionalidad, residencia, idioma, instrucción, capacidad civil o mental, o condena, por juez competente, en proceso penal. (énfasis añadido). 
Corte IDH, aunque, en todo caso, las sentencias de la Corte IDH tienen efectos erga omnes, sobre el Estado parte del sistema interamericano de protección de derechos humanos que haya ratificado la $\mathrm{CADH}$ y aceptado la jurisdicción de la Corte IDH. La Corte IDH, al interpretar la CADH y fallar de manera vinculante, construye los pilares de la seguridad jurídica y la efectividad de los derechos humanos a nivel continental, dando lugar al establecimiento de un "orden público interamericano" de "mínimos" como lo indican Cárcamo y Jiménez (2016, p. 21):

En complemento, el artículo 26 de la Convención de Viena consagra el principio pacta sunt servanda el cual aplicado a la CADH implica que los Estados garanticen de buena fe el respeto y goce de los derechos fundamentales que consagra, por lo que toda interpretación que de este tratado se haga debe favorecer estas prerrogativas y no limitarlas. Una aplicación de este principio conlleva a que los Estados parte de la Convención reconocieran que los pronunciamientos judiciales de la Corte IDH son vinculantes, y los operadores jurídicos de estos tendrían no solo que acatar las disposiciones normativas del tratado en mención, sino también considerar las pautas fijadas por su máximo interprete que es la Corte Interamericana.

Por su parte, existe el deber de vinculación jurídica que deben seguir las autoridades administrativas, judiciales y legislativas de los Estados americanos respecto de las interpretaciones que la Corte IDH como máximo interprete y guardián de la $\mathrm{CADH}$ realice, esto es la aplicación del efecto de "cosa interpretada", a partir del cual las interpretaciones contenidas en las sentencias de este órgano internacional se expanden más allá del caso concreto. 


\section{La jurisprudencia de la Corte IDH sobre limitación de los derechos políticos: breve referencia al Caso Yatama vs. Nicaragua y análisis del Caso Castañeda Gutman vs. Estados Unidos Mexicanos}

Para cotejar o comparar la procedencia de la restricción de los derechos políticos pasivos (derecho a ser elegido) del tránsfuga en República Dominicana, es plausible tener en cuenta algunas de las decisiones pioneras de la Corte IDH sobre limitación legal de derechos políticos, como lo son la sentencia Yatama vs. Nicaragua y el fallo Castañeda Gutman vs. Estados Unidos Méxicanos. ${ }^{11}$

Los citados precedentes judiciales continentales, emanados de la Corte IDH, adquieren relevancia por aplicación del principio de la cosa juzgada formal interamericana - res interpretata-, base del orden público panamericano, puesto que los efectos expansivos de la "cosa interpretada" recae, prima facie, sobre el Estado contra el que la máxima instancia judicial internacional americana encuentra responsable de violación de derechos humanos sin menoscabo del efecto expansivo de su jurisprudencia a los Estados parte de la CAHD que aceptan la competencia jurisdiccional de la Corte IDH. Ello, porque el contenido de la jurisprudencia de dicha instancia judicial continental guarda relación directa con el deber estatal, de cada uno de ellos, de adoptar medidas a nivel nacional y de generar la adecuación normativa interna para cumplir con el deber de promover, asegurar, proteger, garantizar y hacer plenamente efectivos los derechos humanos de toda persona humana habitante de su territorio - a tenor de los artículos 1 y 2 de la CADH - y porque las decisiones de la Corte IDH procuran asegurar la plena

\footnotetext{
11 Por ser materia que excede el presente estudio, se omite entrar a considerar la limitación de los derechos políticos derivadas de decisiones de órganos administrativos que han sido objeto de desarrollo jurisprudencial por la Corte IDH porque afectan el núcleo esencial del derecho político a ser elegido y a la participación política. Véanse, por ejemplo: Caso López Mendoza Vs. Venezuela, sentencia de 1 de septiembre de 2011 y Caso Petro Urrego vs. Colombia, sentencia del 8 de julio de 2020.
}

Via Inveniendi Et Iudicandi

e-ISSN: 1909-0528 | DOI: https://doi.org/10.15332/19090528

Vol. 16 N.o 1 | enero-junio del 2021 
efectividad de los derechos humanos mediante la aplicación de la normativa convencional de la $\mathrm{CADH}$, y demás instrumentos convencionales internacionales.

Debe tenerse en cuenta, del mismo modo, que sus tribunales internos deben interpretar y decidir los casos atendiendo el principio del efecto útil de la CADH mediante el principio de interpretación conforme a lo establecido en la sentencia dotada de cosa juzgada formal internacional y conforme a los estatutos convencionales supranacionales sobre derechos humanos.

El Estado constitucional tiene el deber de promover, respetar, asegurar y proteger los derechos fundamentales, interviniendo los menos posible sobre su goce efectivo, absteniéndose de incurrir en actos arbitrarios u omisiones que de cualquier manera llegue a violarlos sobre la justificación, eso sí, de que los derechos políticos no son absolutos y pueden ser objeto de limitación por el Constituyente primario o por el Legislador, a través de la ley, delegado para el ejercicio legítimo de la función legislativa en y por la Constitución nacional. Veamos entonces, de manera somera los argumentos usados por la Corte IDH para justificar la restricción a los derechos políticos.

\section{Breve referencia a la sentencia de la Corte IDH sobre restricción de derechos políticos en el Caso Yatama vs. Nicaragua}

En este caso, la Corte IDH deja claro que los derechos políticos no son absolutos y pueden ser objeto de limitaciones siempre que sean legítimas y razonables:

206. La previsión y aplicación de requisitos para ejercitar los derechos políticos no constituyen, per se, una restricción indebida a los derechos políticos. Esos derechos no son absolutos y pueden estar sujetos a limitaciones. Su reglamentación debe observar los principios de 
legalidad, necesidad y proporcionalidad en una sociedad democrática. La observancia del principio de legalidad exige que el Estado defina de manera precisa, mediante una ley, los requisitos para que los ciudadanos puedan participar en la contienda electoral, y que estipule claramente el procedimiento electoral que antecede a las elecciones. De acuerdo al artículo 23.2 de la Convención se puede reglamentar el ejercicio de los derechos y oportunidades a las que se refiere el inciso 1 de dicho artículo, exclusivamente por las razones establecidas en ese inciso. La restricción debe encontrase prevista en una ley, no ser discriminatoria, basarse en criterios razonables, atender a un propósito útil y oportuno que la torne necesaria para satisfacer un interés público imperativo, y ser proporcional a ese objetivo. Cuando hay varias opciones para alcanzar ese fin, debe escogerse la que restrinja menos el derecho protegido y guarde mayor proporcionalidad con el propósito que se persigue.

207. Los Estados pueden establecer estándares mínimos para regular la participación política, siempre y cuando sean razonables de acuerdo a los principios de la democracia representativa. Dichos estándares, deben garantizar, entre otras, la celebración de elecciones periódicas, libres, justas y basadas en el sufragio universal, igual y secreto como expresión de la voluntad de los electores que refleje la soberanía del pueblo, tomando en que cuenta que, según lo dispuesto en el artículo 6 de la Carta Democrática Interamericana, "[p]romover y fomentar diversas formas de participación fortalece la democracia”, para lo cual se pueden diseñar”

218. La restricción de participar a través de un partido político impuso a los candidatos propuestos por Yatama una forma de organización ajena a sus usos, costumbres y tradiciones, como requisito para ejercer el derecho a la participación política, [...] 
219. Con base en las anteriores consideraciones, la corte estima que la limitación analizada en los párrafos precedentes constituye una restricción indebida al ejercicio de un derecho político, que implica un límite innecesario al derecho a ser elegido, tomando en cuenta las circunstancias del presente caso, a las que no son necesariamente asimilables todas las hipótesis de agrupaciones para fines políticos que pudieran presentarse en otras sociedades nacionales o sectores de una misma sociedad nacional. (Corte IDH, Caso Yatama vs. Nicaragua, sentencia del 23 de junio de 2005) (énfasis míos)

\section{La Corte IDH, la restricción de derechos políticos en el Caso Castañeda Gutman vs. Estados Unidos Mexicanos y el Test de Convencionalidad de la Restricción}

En este caso, la Corte IDH reconoció que la restricción al derecho político pasivo (derecho a ser elegido) de postulación de la persona como candidato a la Presidencia de la República de México, únicamente a través de los partidos políticos, por mandato de la ley, no constituye, per se, una limitación ilegítima de dicho derecho político. La instancia judicial continental, asimismo, fijó los parámetros del Test de Convencionalidad de la Restricción de Derechos Políticos, el cual será usado como herramienta dogmática para examinar si la limitación legal impuesta por República Dominicana sobre el derecho a ser elegido del tránsfuga se ciñe a las exigencias fijadas por la Corte IDH en esta materia.

Por la relevancia para la situación que deriva de la restricción de la elegibilidad (sufragio pasivo o derecho a ser elegido) del tránsfuga, como consecuencia de actos desleales con sus compañeros de partido y con el partido, al desconocer decisiones de sus instancias de decisión, pactando luego con otros partidos, agrupaciones o movimientos políticos, incurriendo en prácticas de transfuguismo político, se cita textualmente, en extenso, apartes de la sentencia, ya que en su análisis se puede verificar que los derechos políticos (que no son absolutos) pueden ser objeto de 
limitaciones siempre que estén soportadas, de manera razonable, en un Test de Convencionalidad de la Restricción, que consiste en determinar si la limitación del derecho político cumple con los requisitos de 1) legalidad; 2) finalidad; 3) necesidad y proporcionalidad. Se citan textualmente algunos párrafos de la sentencia en mención, emitida por la Corte IDH el 6 de agosto de 2008, así:

155. Por su parte, el párrafo 2 del artículo 23 de la Convención Americana establece que la ley puede reglamentar el ejercicio y las oportunidades a tales derechos, exclusivamente en razón de la "edad, nacionalidad, residencia, idioma, instrucción, capacidad civil o mental, o condena, por juez competente, en proceso penal”. La disposición que señala las causales por las cuales se puede restringir el uso de los derechos del párrafo 1 tiene como propósito único - a la luz de la Convención en su conjunto y de sus principios esenciales- evitar la posibilidad de discriminación contra individuos en el ejercicio de sus derechos políticos. Asimismo, es evidente que estas causales se refieren a las condiciones habilitantes que la ley puede imponer para ejercer los derechos políticos, y las restricciones basadas en esos criterios son comunes en las legislaciones electorales nacionales, que prevén el establecimiento de edades mínimas para votar y ser votado, ciertos vínculos con el distrito electoral donde se ejerce el derecho, entre otras regulaciones. Siempre que no sean desproporcionados o irrazonables, se trata de límites que legítimamente los Estados pueden establecer para regular el ejercicio y goce de los derechos políticos y que se refieren a ciertos requisitos que las personas titulares de los derechos políticos deben cumplir para poder ejercerlos.

\section{$[\ldots]$}

157. Esta obligación positiva consiste en el diseño de un sistema que permita que se elijan representantes para que conduzcan los asuntos públicos. En efecto, para que los derechos políticos puedan ser ejercidos, la ley necesariamente tiene que establecer regulaciones que van más 
allá de aquellas que se relacionan con ciertos límites del Estado para restringir esos derechos, establecidos en el artículo 23.2 de la Convención. Los Estados deben organizar los sistemas electorales y establecer un complejo número de condiciones y formalidades para que sea posible el ejercicio del derecho a votar y ser votado.

$[\ldots]$

166. El sistema interamericano tampoco impone un sistema electoral determinado ni una modalidad específica para el ejercicio de los derechos a votar y a ser votado. La Convención Americana establece lineamientos generales que determinan un contenido mínimo de los derechos políticos y permite a los Estados que dentro de los parámetros convencionales regulen esos derechos de acuerdo a sus necesidades históricas, políticas, sociales y culturales, las que pueden variar de una sociedad a otra, e incluso en una misma sociedad, en distintos momentos históricos ${ }^{12}$.

\subsection{La restricción de los derechos políticos en el presente caso}

[...] Como lo ha establecido anteriormente el Tribunal, la previsión y aplicación de requisitos para ejercitar los derechos políticos no constituyen, per se, una restricción indebida a los derechos políticos. Sin embargo, la facultad de los Estados de regular o restringir los derechos no es discrecional, sino que está limitada por el derecho internacional que exige el cumplimiento de determinadas exigencias que de no ser respetadas transforma la restricción en ilegítima y contraria a la Convención Americana. Conforme a lo establecido en el artículo 29.a

12 La CADH permite la restricción por mandato de la ley del derecho de asociación: "Artículo 16. Libertad de Asociación: 1. Todas las personas tienen derecho a asociarse libremente con fines ideológicos, religiosos, políticos, económicos, laborales, sociales, culturales, deportivos o de cualquiera otra índole. 2. El ejercicio de tal derecho sólo puede estar sujeto a las restricciones previstas por la ley que sean necesarias en una sociedad democrática, en interés de la seguridad nacional, de la seguridad o del orden públicos, o para proteger la salud o la moral públicas o los derechos y libertades de los demás. 3. Lo dispuesto en este artículo no impide la imposición de restricciones legales, y aun la privación del ejercicio del derecho de asociación, a los miembros de las fuerzas armadas y de la policía" (OEA, 1978). (énfasis mío).

Via Inveniendi Et Iudicandi

e-ISSN: 1909-0528 | DOI: https://doi.org/10.15332/19090528

Vol. 16 N.o 1 | enero-junio del 2021 
in fine de dicho tratado ninguna norma de la Convención puede ser interpretada en sentido de limitar los derechos en mayor medida que la prevista en ella.

La Corte ha precisado las condiciones y requisitos que deben cumplirse al momento de regular o restringir los derechos y libertades consagrados en la Convención y procederá a analizar, a la luz de los mismos, el requisito legal bajo examen en el presente caso.

\section{a) Legalidad de la medida restrictiva}

176. El primer paso para evaluar si una restricción a un derecho establecido en la Convención Americana es permitida a la luz de dicho tratado consiste en examinar si la medida limitativa cumple con el requisito de legalidad. Ello significa que las condiciones y circunstancias generales que autorizan una restricción al ejercicio de un derecho humano determinado deben estar claramente establecidas por ley. La norma que establece la restricción debe ser una ley en el sentido formal y material.

177. En el presente caso, la presunta víctima no alegó que la medida restrictiva no estuviera prevista en una ley, sino que su argumentación se dirigió a demostrar que la ley que regula esta materia y su aplicación en su caso concreto estableció una restricción indebida y, por ello, contraria a los derechos políticos consagrados en la Convención Americana.

\section{$[\ldots]$}

179. La Corte observa que el requisito por el cual corresponde a los partidos políticos solicitar el registro de los candidatos a cargos electivos a nivel federal se encuentra previsto en el artículo 175 del COFIPE, una ley en sentido formal y material.

\section{b) Finalidad de la medida restrictiva}


180. El segundo límite de toda restricción se relaciona con la finalidad de la medida restrictiva; esto es, que la causa que se invoque para justificar la restricción sea de aquellas permitidas por la Convención Americana, previstas en disposiciones específicas que se incluyen en determinados derechos [...].

181. A diferencia de otros derechos que establecen específicamente en su articulado las finalidades legítimas que podrían justificar las restricciones a un derecho, el artículo 23 de la Convención no establece explícitamente las causas legítimas o las finalidades permitidas por las cuales la ley puede regular los derechos políticos. En efecto, dicho artículo se limita a establecer ciertos aspectos o razones (capacidad civil o mental, edad, entre otros) con base en los cuales los derechos políticos pueden ser regulados en relación con los titulares de ellos pero no determina de manera explicita las finalidades, ni las restricciones específicas que necesariamente habrá que imponer al diseñar un sistema electoral, tales como requisitos de residencia, distritos electorales y otros. Sin embargo, las finalidades legítimas que las restricciones deben perseguir se derivan de las obligaciones que se desprenden del artículo 23.1 de la Convención, a las que se ha hecho referencia anteriormente. [...]

183. La Corte considera que el artículo 175 del COFIPE bajo examen tiene por finalidad organizar el proceso electoral y el acceso de los ciudadanos al ejercicio del poder público en condiciones de igualdad y de manera eficaz. Dicha finalidad resulta esencial para el ejercicio de los derechos de votar y a ser votado en elecciones periódicas auténticas, por sufragio universal e igual, y por voto secreto que garantice la libre expresión de la voluntad de los electores, de acuerdo con el artículo 23 de la Convención Americana.

184. No obstante, el hecho de que una medida persiga un fin permitido por la Convención no implica que la misma sea necesaria y proporcional, lo que se examinará a continuación. 


\section{c) Necesidad en una sociedad democrática y proporcionalidad de la medida restrictiva}

185. En el sistema interamericano existe un tercer requisito que debe cumplirse para considerar la restricción de un derecho compatible con la Convención Americana. La Corte Interamericana ha sostenido que para que una restricción sea permitida a la luz de la Convención debe ser necesaria para una sociedad democrática. Este requisito, que la Convención Americana establece de manera explícita en ciertos derechos (de reunión, artículo 15; de asociación, artículo 16; de circulación, artículo 22), ha sido incorporado como pauta de interpretación por el Tribunal y como requisito que califica a todas las restricciones a los derechos de la Convención, incluidos los derechos políticos.

\section{La existencia de una necesidad social imperiosa - interés público imperativo}

193. La Corte considera que el Estado ha fundamentado que el registro de candidatos exclusivamente a través de partidos políticos responde a necesidades sociales imperiosas basadas en diversas razones históricas, políticas, sociales. La necesidad de crear y fortalecer el sistema de partidos como respuesta a una realidad histórica y política; la necesidad de organizar de manera eficaz el proceso electoral en una sociedad de 75 millones de electores, en las que todos tendrían el mismo derecho a ser elegidos; la necesidad de un sistema de financiamiento predominantemente público, para asegurar el desarrollo de elecciones auténticas y libres, en igualdad de condiciones; y la necesidad de fiscalizar eficientemente los fondos utilizados en las elecciones. Todas ellas responden a un interés público imperativo. Por el contrario, los representantes no han acercado elementos suficientes que, más allá de lo manifestado en cuanto al descrédito respecto de los partidos políticos y la necesidad de las candidaturas independientes, desvirtúe los fundamentos opuestos por el Estado. 


\section{La exclusividad en la nominación y el medio idóneo menos restrictivo para regular el derecho a ser votado}

197. Como ha sido señalado, la Convención Americana, al igual que otros tratados internacionales de derechos humanos, no establece la obligación de implementar un sistema electoral determinado. Tampoco establece un mandato específico sobre la modalidad que los Estados partes deben establecer para regular el ejercicio del derecho a ser elegido en elecciones populares [...].

198. La Corte observa que en el derecho electoral comparado la regulación del derecho a ser votado respecto de la inscripción de las candidaturas puede implementarse de dos maneras; mediante el sistema de registro de candidatos de forma exclusiva por parte de los partidos políticos, o bien el sistema de registro de candidaturas por parte de los partidos políticos junto con la posibilidad de inscribir candidaturas independientes. En la región puede observarse que existe cierto equilibrio entre los Estados que establecen el sistema de registro exclusivo a cargo de partidos y aquellos que, además, permiten candidaturas independientes.

200. Ninguno de los dos sistemas, el de nominación exclusiva por parte de partidos políticos y el que permite candidaturas independientes, resulta en sí mismo más o menos restrictivo que el otro en términos de regular el derecho a ser elegido consagrado en su artículo 23 de la Convención $[\ldots . .$.$] .$

201. Las candidaturas independientes pueden regularse de manera que faciliten y amplíen el acceso al derecho a ser votado, pero también puede ocurrir que para inscribir candidaturas independientes se establezcan requisitos mayores que los establecidos para nominar a un candidato por un partido político. El sólo hecho de permitir candidaturas independientes no significa que se trate del medio menos restrictivo para regular el derecho a ser votado. Lo esencial es que cualquiera de los dos sistemas que sea elegido haga accesible y garantice el derecho y la 
oportunidad a ser votado previsto en la Convención en condiciones de igualdad.

\section{Proporcionalidad respecto del interés que se justifica y adecuación al logro del objetivo legítimo.}

203. En cuanto a si la medida se ajusta al logro del objetivo legítimo perseguido, en atención a lo anteriormente mencionado, la Corte estima que en el presente caso la exclusividad de nominación por partidos políticos a cargos electivos de nivel federal es una medida idónea para producir el resultado legítimo perseguido de organizar de manera eficaz los procesos electorales con el fin de realizar elecciones periódicas, auténticas, por sufragio universal e igual, y por voto secreto que garantice la libre expresión de la voluntad de los electores de acuerdo a lo establecido por la Convención Americana.

204. Finalmente, la Corte considera que ambos sistemas, uno construido sobre la base exclusivamente de partidos políticos, y otro que admite también candidaturas independientes, pueden ser compatibles con la Convención y, por lo tanto, la decisión de cuál sistema escoger está en las manos de la definición política que haga el Estado, de acuerdo con sus normas constitucionales. A la Corte no se le escapa que en la región existe una profunda crisis en relación con los partidos políticos, los poderes legislativos y con quienes dirigen los asuntos públicos, por lo que resulta imperioso un profundo y reflexivo debate sobre la participación y la representación política, la transparencia y el acercamiento de las instituciones a las personas, en definitiva, sobre el fortalecimiento y la profundización de la democracia. La sociedad civil y el Estado tienen la responsabilidad, fundamental e inexcusable de llevar a cabo esta reflexión y realizar propuestas para revertir esta situación. En este sentido los Estados deben valorar de acuerdo con su desarrollo histórico y político las medidas que permitan fortalecer los derechos políticos y la democracia, y las candidaturas independientes pueden ser uno de esos mecanismos, entre muchos otros. 
205. Con base en los anteriores argumentos, la Corte no considera probado en el presente caso que el sistema de registro de candidaturas a cargo de partidos políticos constituya una restricción ilegítima para regular el derecho a ser elegido previsto en el artículo 23.1.b de la Convención Americana y, por lo tanto, no ha constatado una violación al artículo 23 de dicho tratado. (Corte IDH, Sentencia del caso Castañeda Gutman vs. Estados Unidos Mexicanos del 6 de agosto de 2008). (énfasis mío)

\section{Test de convencionalidad de la restricción legal del derecho al sufragio pasivo (limitación de la elegibilidad) del tránsfuga como consecuencia de prácticas de transfuguismo político previstas en la legislación dominicana}

A continuación, se hace un examen de la limitación al derecho político (sufragio pasivo) que recae contra la persona del tránsfuga político por actos de deslealtad partidista y electoral contra el anterior partido en el que militaba. Esta revisión se hace para verificar si la limitación al goce del derecho político cumple con las exigencias de legalidad, finalidad, necesidad y proporcionalidad que hagan razonable la medida, teniendo como referencia el Test de Convencionalidad de la Restricción del derecho político fijada por la Corte IDH en la jurisprudencia (res interpretata) del caso Castañeda Gutman Vs. Estados Unidos Mexicanos, cuyos parámetros dogmáticos son tenidos como un referente a la hora de analizar la legalidad, finalidad, proporcionalidad y necesidad de la limitación legal que afecta el derecho político pasivo del sujeto transgresor.

\section{Legalidad de la medida restrictiva}

La prohibición de las prácticas de transfuguismo político, que conducen a la restricción del derecho político del tránsfuga de ser postulado como candidato por partido político distinto, está expresamente consagrada en 
la Ley 15 de 2019 y en la Ley 33 de 2018 con la finalidad de fortalecer el sistema de partidos, agrupaciones y movimientos políticos consustanciales al régimen democrático en el Estado constitucional. Sin partidos políticos fuertes, unidos y fortalecidos languidece la democracia.

\section{Finalidad de la medida restrictiva}

La Ley 15 de 2019 (Ley Orgánica del Régimen Electoral) en el Título I, sobre principios generales, artículo 2, expresamente define tránsfuga y transfuguismo.

En el artículo 134 estatuye el transfuguismo en las candidaturas:

Las personas que hayan sido nominadas para ser postuladas por un partido, agrupación, movimiento político o alianza a la cual pertenezca el mismo, a un cargo de elección, no podrán ser postuladas por ningún otro partido, agrupación, movimiento político o alianza, en el mismo proceso electoral.

Además, el artículo 135 se refiere a la nominación de candidatos:

La nominación de los candidatos a cargos electivos que hayan de ser propuestos por un partido político, deberá ser hecha por el voto afirmativo de la mayoría de los concurrentes a las elecciones primarias, convenciones o mecanismos de selección interna, que conforme con sus estatutos convoquen para tales fines las autoridades correspondientes de conformidad con la ley.

La Ley 33 de 2018 (Partidos, Agrupaciones y Movimientos Políticos) incluye lo siguiente:

Considerando primero: Que los partidos, agrupaciones y movimientos políticos son asociaciones fundamentales e indispensables del sistema democrático. 
Considerando segundo: Que a la vida democrática del país le resulta impostergable el fortalecimiento institucional de los partidos, agrupaciones y movimientos políticos, perfeccionando el régimen jurídico que los rige y potencializando el cumplimiento de sus deberes y derechos.

$[\ldots]$

Considerando cuarto: Que los partidos, agrupaciones y movimientos políticos son organizaciones dotadas de personería jurídica, integradas por ciudadanos y ciudadanas, cuyos propósitos y funciones son de naturaleza esencialmente pública e íntimamente vinculadas al ordenamiento jurídico del sistema de gobierno y del Estado dominicano.

No cabe duda de que la finalidad es fortalecer los partidos, agrupaciones y movimientos políticos, incentivar la confianza ciudadana en estos en tiempos de indignación y descrédito, consolidar la democracia mediante la participación y afiliación a tales instituciones, de carácter político, habida cuenta de la interrelación e interdependencia entre el Estado constitucional, los derechos humanos y la democracia, para lo cual resulta imprescindible en funcionamiento adecuado, transparente y creíble de los partidos, agrupaciones y movimientos políticos.

La finalidad, además, es evitar la traición de los compañeros de partido, prevenir la deslealtad contra partidos, agrupaciones y movimientos políticos, restringiendo la elegibilidad del tránsfuga que no acepta los resultados electorales que le son adversos y pacta con fuerzas políticas contrarias, sin reparar en diferencias ideológicas ni programáticas, movidos por el afán de la obtención del poder político, así destruyan el sistema de partidos y afecten ostensiblemente el régimen democrático y el ordenamiento constitucional. 


\section{Necesidad en una sociedad democrática y proporcionalidad de la medida restrictiva}

La existencia de un sistema de partidos, agrupaciones y movimientos políticos es esencial para la vitalidad de la democracia, para la vigencia

efectiva de los derechos fundamentales y para la consolidación del Estado democrático constitucional, máxime si se tiene en cuenta, como afirman Caldera Ynfante (2018; 2019; 2020a, 2020b) y Caldera Ynfante et ál. (2018; 2019), que la democracia es un derecho fundamental, siendo los partidos, agrupaciones y movimientos políticos el medio y el fin para la materialización de la participación ciudadana en la procura del poder político, y para la formación, gestión y control de la función pública y del funcionamiento efectivo de la persona humana en la comunidad política, sobre el cuidado de la vida y la protección de la persona, en aras de alcanzar la materialización de su proyecto de vida valioso, contando con oportunidades para desarrollar sus capacidades y medios materiales e inmateriales para una existencia digna que le posibiliten lograr florecimiento humano, ser felices y contribuir al bien común.

\section{La existencia de una necesidad social imperiosa e interés público imperativo}

En República Dominicana, el Congreso consideró que para generar transparencia, fortalecer liderazgos y consolidar la democracia es necesario incentivar la lealtad de los líderes para con sus partidos, agrupaciones y movimientos políticos, sancionando la traición partidista con la restricción del derecho político al sufragio pasivo contra el tránsfuga político como una medida de saneamiento ("profilaxis") legislativo de las prácticas que atentan contra la institucionalidad democrática la debilitar el sistema de partidos, agrupaciones y movimientos políticos. 
Así como el caudillismo, el clientelismo, el mesianismo y la politiquería afectan la política, como expresión de servicio a favor de la población, y la calidad de la democracia al golpear directamente a los partidos agrupaciones y movimientos políticos. El transfuguismo político produce daños enormes a la confianza ciudadana en sus liderazgos y sus instituciones democráticas, de allí que, con su tipificación legal se busca evitar los saltos de talanquera, se procura cerrarle las puertas - en otros partidos - a aquellos candidatos que pierdan dentro de cualquier organización, en las elecciones primarias, quienes no podrán postularse por otro partido de cara a las elecciones 2020. Estas disposiciones están reunidas en la Ley 15 de 2019 y la Ley 33 de 2018, desarrolladas luego en el reglamento para la escogencia de candidatos mediante convenciones o encuesta dictado por la Junta Central Electoral (JCE) en virtud de la ley de partidos políticos.

Era necesario e imperioso expedir una ley para evitar que aquellos que aspiraran a determinados puestos en sus partidos no pudieran pactar con otras organizaciones, dando un salto de una organización a otra, luego de haber salido derrotados en las elecciones internas primarias abiertas, por ser una práctica de transfuguismo oportunista, desleal, carente de ética y netamente reprochable por la comunidad política y por el Congreso mediante la ley dictada para restringir derechos políticos (sufragio pasivo) a los tránsfugas.

Aquí cabe citar un parte de la sentencia del caso Castañeda Gutman Vs México sobre la importancia que aquella le otorga a los partidos políticos y que la Corte IDH destaca:

La Corte considera que el Estado ha fundamentado que el registro de candidatos exclusivamente a través de partidos políticos responde a necesidades sociales imperiosas basadas en diversas razones históricas, políticas, sociales. La necesidad de crear y fortalecer el sistema de

Via Inveniendi Et Iudicandi

e-ISSN: 1909-0528 | DOI: https://doi.org/10.15332/19090528

Vol. 16 N. ${ }^{\circ} 1$ | enero-junio del 2021 
partidos como respuesta a una realidad histórica y política; la necesidad de organizar de manera eficaz el proceso electoral en una sociedad de 75 millones de electores, en las que todos tendrían el mismo derecho a ser elegidos; la necesidad de un sistema de financiamiento predominantemente público, para asegurar el desarrollo de elecciones auténticas y libres, en igualdad de condiciones; y la necesidad de fiscalizar eficientemente los fondos utilizados en las elecciones. Todas ellas responden a un interés público imperativo. Por el contrario, los representantes no han acercado elementos suficientes que, más allá de lo manifestado en cuanto al descrédito respecto de los partidos políticos y la necesidad de las candidaturas independientes, desvirtúe los fundamentos opuestos por el Estado (Corte IDH, Sentencia del caso Castañeda Gutman vs. Estados Unidos Mexicanos del 6 de agosto de 2008)

\section{La exclusividad en la nominación y el medio idóneo menos restrictivo para regular el derecho a ser votado}

La consagración de la figura del transfuguismo en la ley dominicana tiene un carácter exclusivo y responde al propósito del Legislador de depurar la práctica político-electoral y fortalecer la democracia, consolidando el sistema de partidos. El medio menos restrictivo consiste en la imposición de una restricción temporal y puntual sobre el derecho político pasivo del tránsfuga, generando una limitación transitoria (inhabilidad coyuntural para ser candidato en el mismo proceso electoral, no pudiendo ser elegido en el mismo) a todo aquel que pretenda desconocer resultados electorales que le hayan sido adversos. Esta medida actúa en defensa del interés general (confianza de los electores-sistema democrático-sistema de partidos), por la cual el tránsfuga queda impedido de participar en el mismo proceso electoral, sin que este llegue a perder o deja de gozar, de manera definitiva, sus derechos políticos. La restricción que padece el tránsfuga de participar en el mismo proceso electoral con partido diferente 
es equiparable a una inhabilidad transitoria y parcial, que no le impide, para otro proceso electoral diferente, que sea elegido y no es óbice para que tenga garantías electorales y cuente con la oportunidad a ser votado conforme a lo previsto en la norma convencional y en la Constitución dominicana.

\section{Proporcionalidad respecto del interés que se justifica y adecuación al logro del objetivo legítimo}

La adopción de la restricción del derecho político del sufragio pasivo del tránsfuga (quien, verbigracia, siendo derrotado en un proceso electoral interno, cambia de organización política para competir durante los mismos comicios), consistente en la limitación legal de no poder ser postulado como candidato por partidos políticos diferentes - restricción de derecho político personal - es proporcional al beneficio que la medida procura en función del interés general y el bien común que representa el hecho de contar con un sistema de partidos vigoroso y funcional, factor decisivo para el goce del derecho fundamental a la democracia, piedra angular para la vigencia y satisfacción de todos los derechos fundamentales por todos los dominicanos. Entre premiar la deslealtad en que incurre el tránsfuga contra sus compañeros y su anterior partido político, restringiéndole temporalmente sus derechos políticos pasivos, para defender los partidos como expresión del sistema democrático y permitirle participar políticamente como candidato, pactando de manera desleal con otras organizaciones políticas, el Legislador dominicano optó por limitar el derecho político del tránsfuga para ser candidato en el mismo proceso electoral donde ha incurrido en tales prácticas.

Entre el legítimo derecho político del tránsfuga y la preservación de la confianza de los electores en la legalidad, idoneidad, transparencia de las decisiones partidistas, la "salud" del sistema democrático y del sistema de 
partidos políticos, el Legislador dominicano razonó y concluyó, en la Ley 33 de 2018, que la restricción al derecho político de la referencia es necesaria y está justificada porque los partidos, agrupaciones y movimientos políticos son "asociaciones fundamentales del sistema democrático", que deben cumplir con sus derechos y deberes y que, como organizaciones, tienen "personería jurídica, integradas por ciudadanos y ciudadanas, cuyos propósitos y funciones son de naturaleza esencialmente públicas e íntimamente vinculadas al ordenamiento jurídico del sistema de gobierno y del Estado dominicano".

\section{Concordancia del test de convencionalidad de la restricción del derecho político con la técnica argumentativa del principio de proporcionalidad}

La restricción del derecho político pasivo de aquel que incurre en transfuguismo política, por deslealtad partidaria, fijada por la legislación dominicana, antes citada, cumple, asimismo, con los parámetros argumentativos del principio de proporcionalidad en materia de limitación de derecho fundamentales. Al razonar sobre dicho instituto procesal, la Corte Constitucional de Colombia, Sentencia C-022 de 1996, sentó lo siguiente:

El concepto de proporcionalidad comprende tres conceptos parciales: la adecuación de los medios escogidos para la consecución del fin perseguido, la necesidad de la utilización de esos medios para el logro del fin (esto es, que no exista otro medio que pueda conducir al fin y que sacrifique en menor medida los principios constitucionales afectados por el uso de esos medios), y la proporcionalidad en sentido estricto entre medios y fin, es decir, que el principio satisfecho por el logro de este fin no sacrifique principios constitucionalmente más importantes. (C. C., Sentencia C-022/96) 
La Corte Constitucional colombiana, al fallar un caso de naturaleza similar - limitaciones a derechos políticos y electorales - en Sentencia C-551 de 2003, señaló:

En tratándose a limitaciones a derechos políticos y electorales, estos son derechos fundamentales que se componen de un núcleo o contenido esencial determinado por las normas internacionales, en este caso por el artículo 23 de la Convención que señala las causales para realizar la restricción a la que hubiere lugar. Sin embargo de acuerdo a lo sentado por la Corte IDH estas restricciones deben guardar respeto por la legalidad, deben tener un fin constitucionalmente legitimo, y finalmente deben ser necesarias en una sociedad democrática, lo cual es claramente una expresión de la aplicación del principio de proporcionalidad.

En conclusión, los beneficios producto de la restricción o limitación a los derechos políticos y electorales deben ser una compensación frente a las cargas que deba soportar el titular de dichos derechos y la sociedad en general; de lo contrario, esta limitación carece de legitimidad y por tanto es inconstitucional. (C. C., Sentencia C-551/03)

Finalmente, sobre la técnica hermenéutica del principio de proporcionalidad, la Corte Constitucional colombiana en Sentencia C-916 de 2002 ha indicado:

En la jurisprudencia constitucional el postulado de la proporcionalidad constituye una directiva no explícitamente positivizada en la Carta Política. Desde un punto de vista abstracto, la proporcionalidad es un concepto relacional cuya aplicación busca colocar dos magnitudes en relación de equilibrio. El concepto de la proporcionalidad remite a la relación de equilibrio entre distintos pares de conceptos, como supuesto de hecho y consecuencia jurídica, afectación y defensa, ataque y reacción. Históricamente la proporcionalidad se ha asociado a conceptos e imágenes como la balanza, la regla o el equilibrio. 
[...] En sentido constitucional, la proporcionalidad es un principio de corrección funcional de toda la actividad estatal que, junto con otros principios de interpretación constitucional - unidad de la Constitución, fuerza normativa, fuerza integradora, concordancia práctica, armonización concreta, inmunidad de los derechos constitucionales e interpretación conforme a la Constitución-, busca asegurar que el poder público, actúe dentro del marco del Estado de derecho, sin excederse en el ejercicio de sus funciones. Su fundamento normativo último está dado por los principios fundamentales de Estado de Derecho (artículo 1, C. P.), fuerza normativa de la Constitución (artículo 4C. P.) y carácter inalienable de los derechos de la persona humana (artículo 5, C. P.). (C. C., Sentencia C-916/02)

\section{Conclusiones}

Del examen efectuado a la legislación electoral dominicana se puede concluir que en su articulado sanciona la conducta de la perfidia política y la deslealtad política de los actores que buscan obtener el poder político, como mecanismo para fortalecer el sistema de partidos, la confianza de la comunidad en estos y sus protagonistas y la consolidación de la democracia constitucional. No obstante, al margen de la regulación legal electoral, que limita los cambios de bando político por motivaciones de interés particular, por legítimas que parezcan, dichas conductas no son castigadas de manera efectiva en función de la preservación de la democracia y el sistema de partidos como bienes jurídicamente tutelados. La perfidia político-electoral, en República Dominicana es castigada con la restricción parcial y temporal del goce de los derechos políticos pasivos (derecho a ser elegido) de la persona natural transgresora de la regulación. Tal regulación sancionatoria, de acuerdo con lo examinado, cumple con los estándares internacionales establecidos en el derecho convencional de los derechos humanos y demás normas supranacionales integradoras del bloque de constitucionalidad que, en el caso dominicano, tienen jerarquía 
prevalente por mandato constitucional. Se aprecia, igualmente, que en la nuda efectividad del sistema de sanciones frente a la práctica del transfuguismo político-electoral - que lastra la solidez y confiabilidad de la democracia - gravitan diversos factores de índole extralegal arraigados en la comunidad política.

Así, ante una situación política fáctica que parecía estar inmersa dentro de la causal de inhabilitación parcial y temporal de los derechos políticos del presunto infractor, pasó inadvertida y sin reprimendas legales e institucionales por parte de los órganos encargados de hacer valer las sanciones regulatorias previstas frente a tal contravención legal. Es posible que hayan primado fuertes consideraciones de carácter político para dejar concurrir al presunto infractor en las elecciones presidenciales en atención a que su participación en la carrera presidencial sería un mal menor frente a una eventual inhabilitación político-electoral de su candidatura, que, adoptada en derecho, lo hubiese victimizado ante el país y la región, ya que en este tipo de circunstancias, a la hora de la implementación de los correctivos previstos en las normas para prevenir todo tipo de deslealtad partidista, se demuestra que no basta simplemente su consagración expresa en la regulación legal.

Al contrario, para su vigencia y aplicación eficaz se requiere un férreo compromiso institucional de los órganos competentes del Estado que, para hacer valer la ley, se tienen que colocar por sobre todo tipo de consideraciones extrajurídicas, es decir, dejar de lado las motivaciones políticas, de cálculo partidista, de carácter comunicacional o hasta de naturaleza económica, y que pueden llegar a rebasar, en el campo práctico de la contienda política y electoral, la efectividad de las normas legales sancionatorias del transfuguismo político, afectando, a la postre, el régimen constitucional, la confianza ciudadana en la política, la solidez de 
los partidos políticos y la calidad de la democracia, vista como un derecho fundamental.

\section{Referencias}

Cárcamo, M. C. y Jiménez, D. C. (2016). Limitaciones a derechos políticos y electorales en la Convención Americana de Derechos Humanos y en Colombia (tesis, Universidad de Cartagena). https://repositorio.unicartagena.edu.co/handle/11227/2859

Caldera Ynfante, J. (2012). El Bloque de Constitucionalidad como herramienta de protección de los derechos fundamentales. Una aproximación al estudio de sus aportes desde el Derecho Procesal Constitucional. Memoria del Tercer Congreso Colombiano de Derecho Procesal Constitucional y Segundo encuentro de la Asociación Mundial de Justicia Constitucional: Asociación Colombiana de Derecho Procesal Constitucional, Cali (Vol. 23). En E. Velandia (Dir.), Derecho Procesal Constitucional, Tomo III, Volumen I (pp. 223-255). VC Editores; ACDP.

Caldera Ynfante, J. (2018). La democracia como derecho fundamental: Ideas sobre un modelo de democracia integral. Opción Revista de Ciencias Humanas y Sociales, 34(87), 584-624. https://produccioncientificaluz.org/index.php/opcion/article/view/23891

Caldera Ynfante, J., De los Santos, I. y Ávila, F. M. (2018). La forja del Estado democrático constitucional en Venezuela y su relación con la democracia integral. Utopía y Praxis Latinoamericana, 23(2), 3-22. https://www.redalyc.org/articulo.oa?id=27957770016

Caldera Ynfante, J. (2019). Democracia integral: Un derecho fundamental para el logro de la dignidad humana, el proyecto de vida valioso y la felicidad social. Nueva Jurídica.

https://www.academia.edu/40139619/LA DEMOCRACIA COMO DERECHO F UNDAMENTAL DEMOCRACIA INTEGRAL JES\%C3\%9AS CALDERA YNFAN $\underline{\text { TE PhD Libro }}$

Via Inveniendi Et Iudicandi

e-ISSN: 1909-0528 | DOI: https://doi.org/10.15332/19090528

Vol. 16 N.o 1 | enero-junio del 2021 
Caldera Ynfante, J., Ávila, F. M., Woolcott, O. y Martín, V. (2019). Biopoder, biopolítica, justicia restaurativa y criminología crítica: una perspectiva alternativa de análisis del sistema penitenciario colombiano. Utopía y Praxis Latinoamericana: Revista Internacional de Filosofía Iberoamericana y Teoría Social, 24(2), 169-189. https://dialnet.unirioja.es/servlet/articulo?codigo $=7113211$

Caldera Ynfante, J. (2020a). Biocracia y derecho fundamental al nuevo orden mundial en la postpandemia covid-19. Utopía y Praxis Latinoamericana: Revista Internacional de Filosofía Iberoamericana y Teoría Social, 25(4), 33-49. https://produccioncientificaluz.org/index.php/utopia/article/view/32845

Caldera Ynfante, J. (2020b). Intervención humanitaria electoral: El Consejo de Seguridad de la ONU y la superación del conflicto político en Venezuela. Revista Opción, 36(92), 491-555. https://produccioncientificaluz.org/index.php/opcion/article/view/32692

Comisión Interamericana de Derechos Humanos. (2009). Informe anual de la Comisión Interamericana de Derechos Humanos 2009, capítulo IV, Venezuela. https://www.cidh.oas.org/annualrep/2009sp/cap.4Venezuelaog.sp.htm

Comisión Interamericana de Derechos Humanos. (2003). Informe anual de la Comisión Interamericana de Derechos Humanos 2003, capítulo IV, Cuba. https://www.cidh.oas.org/annualrep/2003sp/cap.4a.htm

Comisión Interamericana de Derechos Humanos. (1990). Informe anual de la Comisión Interamericana de Derechos Humanos 1990-1991, capítulo IV, Haití. https://www.cidh.oas.org/annualrep/90.91sp/Cap.4a.htm

Constitución Política de la República Dominicana. 13 de junio de 2015.

Corte Constitucional de Colombia. 23 de enero de 1996, M. P.: C. Gaviria Díaz, Sentencia C-022 de 1996.

Corte Constitucional de Colombia. 19 de julio de 2003, M. P.: E. Montealegre Lynett, Sentencia C-551 de 2003.

Corte Constitucional de Colombia. 29 de octubre de 2002, M. P.: M. Cepeda Espinosa, Sentencia C-916 de 2002.

Corte Interamericana de Derechos Humanos. Caso Yatama vs. Nicaragua. Sentencia del 23 de junio de 2005 .

Via Inveniendi Et Iudicandi

e-ISSN: 1909-0528 | DOI: https://doi.org/10.15332/19090528

Vol. 16 N. ${ }^{\circ} 1$ | enero-junio del 2021 
Corte Interamericana de Derechos Humanos. Caso Castañeda Gutman vs. Estados Unidos Mexicanos. Sentencia del 6 de agosto de 2008.

Corte Interamericana de Derechos Humanos. Caso Manuel Cepeda Vargas vs. Colombia. Sentencia del 26 de mayo de 2010.

Corte Interamericana de Derechos Humanos. Caso López Mendoza Vs. Venezuela. Sentencia del 1 de septiembre de 2011.

Corte Interamericana de Derechos Humanos. Caso Petro Urrego vs. Colombia. Sentencia del 8 de julio de 2020.

Cortés Zambrano, S. (2009). La sociedad civil en el contexto de la globalización. Una nueva perspectiva de la democracia. Via Inveniendi et Iudicandi, 4(2), 94-116. https://doi.org/10.15332/s1909-0528.2009.0002.05

Cortés Zambrano, S. (2013). La globalización económica y los derechos humanos. Revista Via Inveniendi et Iudicandi, vol. 8, No. 2, PP.138-149.

Dalla Via, A. R. (2011). Los derechos políticos en el Sistema Interamericano de Derechos Humanos. Justicia Electoral. Revista del Tribunal Electoral del Poder Judicial de la Federación, 8, 15-79.

Hernández, M. (1995). Constitución y derechos fundamentales. Boletín Mexicano de Derecho Comparado, 84, 1041-1051.

Organización de las Naciones Unidas. Pacto Internacional de Derechos Civiles y Políticos. 23 de mayo de 1976.

Organización de las Naciones Unidas. Compilation of general comments and general recommendations adopted by Human Rights Treaty bodies. HRI/GEN/1/Rev.7. 12 de mayo de 2004.

Organización de los Estados Americanos. Convención Americana sobre Derechos Humanos (Pacto de San José). 18 de julio de 1978.

Piza Escalante, R. (1979). Sistema Interamericano y Universal de Protección de los Derechos Humanos. Revista de Ciencias Jurídicas, 38.

República Dominicana. Ley 33 de 2018. Partidos, Agrupaciones y Movimientos Políticos. 15 de agosto de 2018. Gaceta Oficial n. ${ }^{\circ} 10.917$.

República Dominicana. Ley 15 de 2019. Ley Orgánica de Régimen Electoral. 20 de febrero de 2019. Gaceta Oficial n. ${ }^{\circ} 10.933$.

Via Inveniendi Et Iudicandi

e-ISSN: 1909-0528 | DOI: https://doi.org/10.15332/19090528

Vol. 16 N. ${ }^{\circ} 1$ | enero-junio del 2021 
República Dominicana. Ley 33 de 2018. Partidos, Agrupaciones y Movimientos Políticos. 15 de agosto de 2018. Gaceta Oficial n. ${ }^{\circ} 10.917$.

Rincón, K. y Peñas, A (2015). El delito político en Colombia frente al Derecho Internacional Humanitario. Revista IUSTA, 43, 67-90. http://revistas.usta.edu.co/index.php/iusta/article/view/2538/2470

Rodríguez, A. (2014). Indicadores de constitucionalidad de las políticas públicas: enfoque de gestión de derechos. Revista Via Inveniendi et Iudicandi, 9(2), 135-175.

Via Inveniendi Et Iudicandi

e-ISSN: 1909-0528 | DOI: https://doi.org/10.15332/19090528

Vol. 16 N.o 1 | enero-junio del 2021 